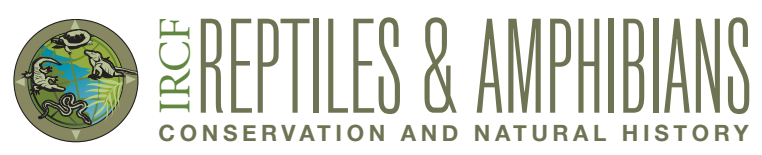

\title{
Observations of Agror Agamas, Laudakia agrorensis (Stoliczka 1872) (Sauria: Agamidae), in the Doda District, Jammu and Kashmir, India
}

Amit Manhas ${ }^{1}$, Rajni Raina ${ }^{2}$, and Ashwani Wanganeo ${ }^{1}$

${ }^{1}$ Department of Environmental Sciences and Limnology, Barkatullah University Bhopal, Madhya Pradesh, India (amitmanhas1986@gmail.com) ${ }^{2}$ Department of Zoology, Government Science and Commerce College-Benazir, Bhopal, Madhya Pradesh, India

Aror Agamas, Laudakia agrorensis (Stoliczka 1872; Fig. 1), Aalso known as Asian Rock Agamas, range through eastern Afghanistan, northwestern India (Punjab, Himachal Pradesh, Jammu and Kashmir), and northern Pakistan at elevations of 700-1,300 m (Stoliczka 1872; Smith 1935; Baig et al. 2012; Uetz et al. 2017).

Duda and Sahi (1977, 1978), Sahi (1979), and Sahi and Duda $(1982,1985,1986)$ reported the results of herpeto- logical surveys in Jammu and Kashmir State, but no one has since then addressed the herpetofauna of the Doda District. From March to mid-June in 2014 and 2015, during efforts to monitor the effects of changing climatic regimes on the reptilian fauna, we conducted surveys in the mountainous region above the Chenab Valley $\left(33^{\circ} 08^{\prime} \mathrm{N}, 75^{\circ} 32^{\prime} \mathrm{E}\right.$, average elevation 1,107 $\mathrm{m}$ asl) in the Shiwalik Range of the Middle Himalayas (Table 1).
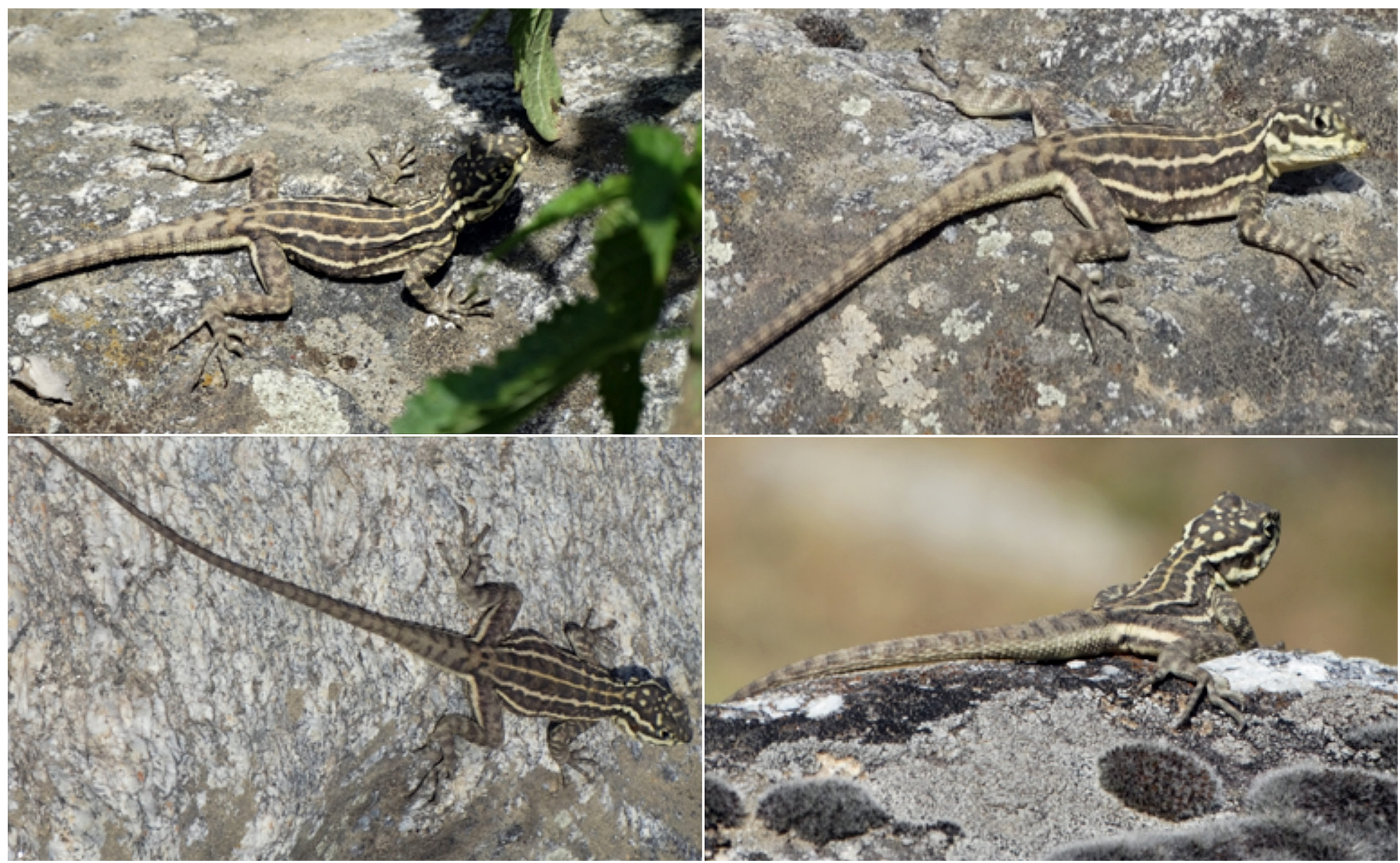

Fig. 1. Adult Agror Agamas (Laudakia agrorensis) encountered in the Doda Region, Jammu and Kashmir, India. Photographs by Amit Manhas. 
Table 1. Sampling sites in the Doda Region.

\begin{tabular}{lcc} 
Site & \multicolumn{1}{c}{ Location } & Elevation asl \\
\hline Nai-Bhallara & $33^{\circ} 05^{\prime} 20.69^{\prime \prime} \mathrm{N}, 75^{\circ} 42^{\prime} 30.24 ” \mathrm{E}$ & $1,693-2,328 \mathrm{~m}$ \\
\hline Village Chagsoo & $33^{\circ} 07^{\prime} 33.27^{\prime \prime} \mathrm{N}, 75^{\circ} 40^{\prime} 11.50^{\prime \prime} \mathrm{E}$ & $1,097-2,269 \mathrm{~m}$ \\
\hline Village Zazinda & $33^{\circ} 5^{\prime} 34.48^{\prime \prime} \mathrm{N}, 75^{\circ} 38^{\prime} 19.744^{\prime} \mathrm{E}$ & $1,566-2,306 \mathrm{~m}$ \\
\hline Bhaderwah City & $32^{\circ} 58^{\prime} 47.89^{\prime \prime} \mathrm{N}, 75^{\circ} 42^{\prime} 57.27^{\prime \prime} \mathrm{E}$ & $1,514-1,829 \mathrm{~m}$ \\
\hline Doda City & $33^{\circ} 08^{\prime} 34.41^{\prime \prime} \mathrm{N}, 75^{\circ} 32^{\prime} 47.33^{\prime \prime} \mathrm{E}$ & $975-1,282 \mathrm{~m}$ \\
\hline
\end{tabular}

We encountered Agror Agamas during May and June at three (Nai-Bhallara, Village Chagsoo, and Village Zazinda) of five sites sampled (Fig. 2). Ambient air temperatures where lizards were seen were $19-24^{\circ} \mathrm{C}$ and elevations ranged from 1,216 to $2,198 \mathrm{~m}$ asl. Microhabitats included rocky areas near a stream, bushes, and fallen tree trunks, with the largest number of lizards associated with rocks in areas of sparse vegetation (Fig. 3).

The largest individual we encountered (total length = $295 \mathrm{~mm}, \mathrm{SVL}=95 \mathrm{~mm}$ ) was exactly the same size as the largest documented by Sahi (1979). Smith (1935) reported the species from Punjab (Agror Valley) and Kashmir (Jhelum Valley), and Sahi (1979) documented the species in Nandani, Mansar Village, and Ramban during April 1976 and in June and July 1997, respectively; our records extend the known range of the species in Doda District approximately $40 \mathrm{~km}$ to the west (Fig. 2). Our maximum recorded elevation of 2,198 $\mathrm{m}$ asl at Village Zazinda in the Doda District is substantially higher than the elevational range (approximately $700-1,300 \mathrm{~m}$ asl) reported by Baig et al. (2012) in Pakistan and Kashmir.

\section{Literature Cited}

Baig, K.J., P. Wagner, B.A. Natalia, and W. Böhme. 2012. A morphology-based taxonomic revision of Laudakia Gray, 1845 (Squamata: Agamidae). Vertebrate Zoology 62: 213-260.

Duda, P.L. and D.N. Sahi. 1977. An uptodate checklist of herptiles of Jammu \& Kashmir. Jammu and Kashmir University Review 6(10): 1-7.

Duda, P.L. and D.N. Sahi. 1978. Cyrtodactylus himalayanus: A new gekkonid spe-

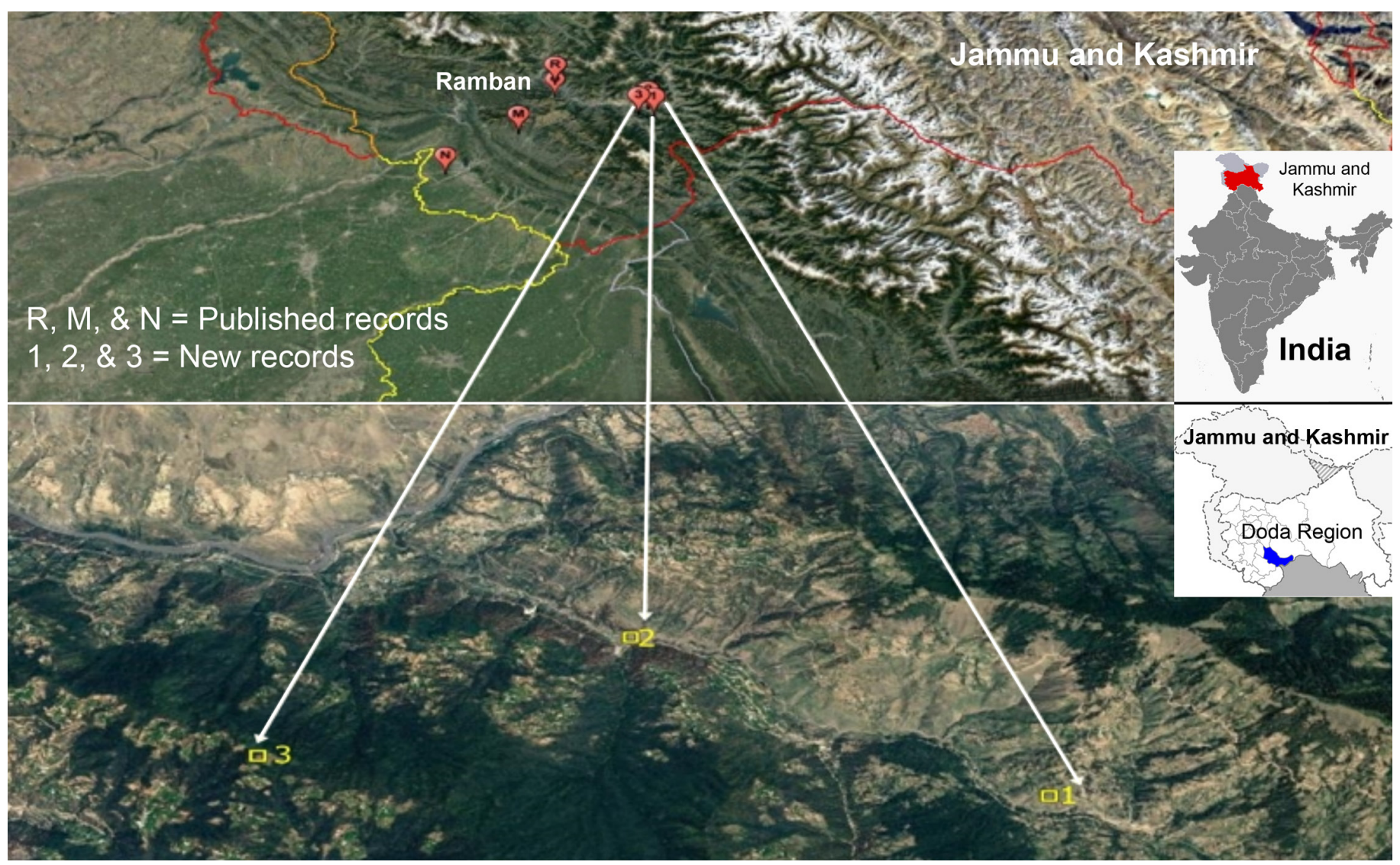

Fig. 2. Published and new records of Agror Agamas (Laudakia agrorensis) in Jammu and Kashmir, India. 


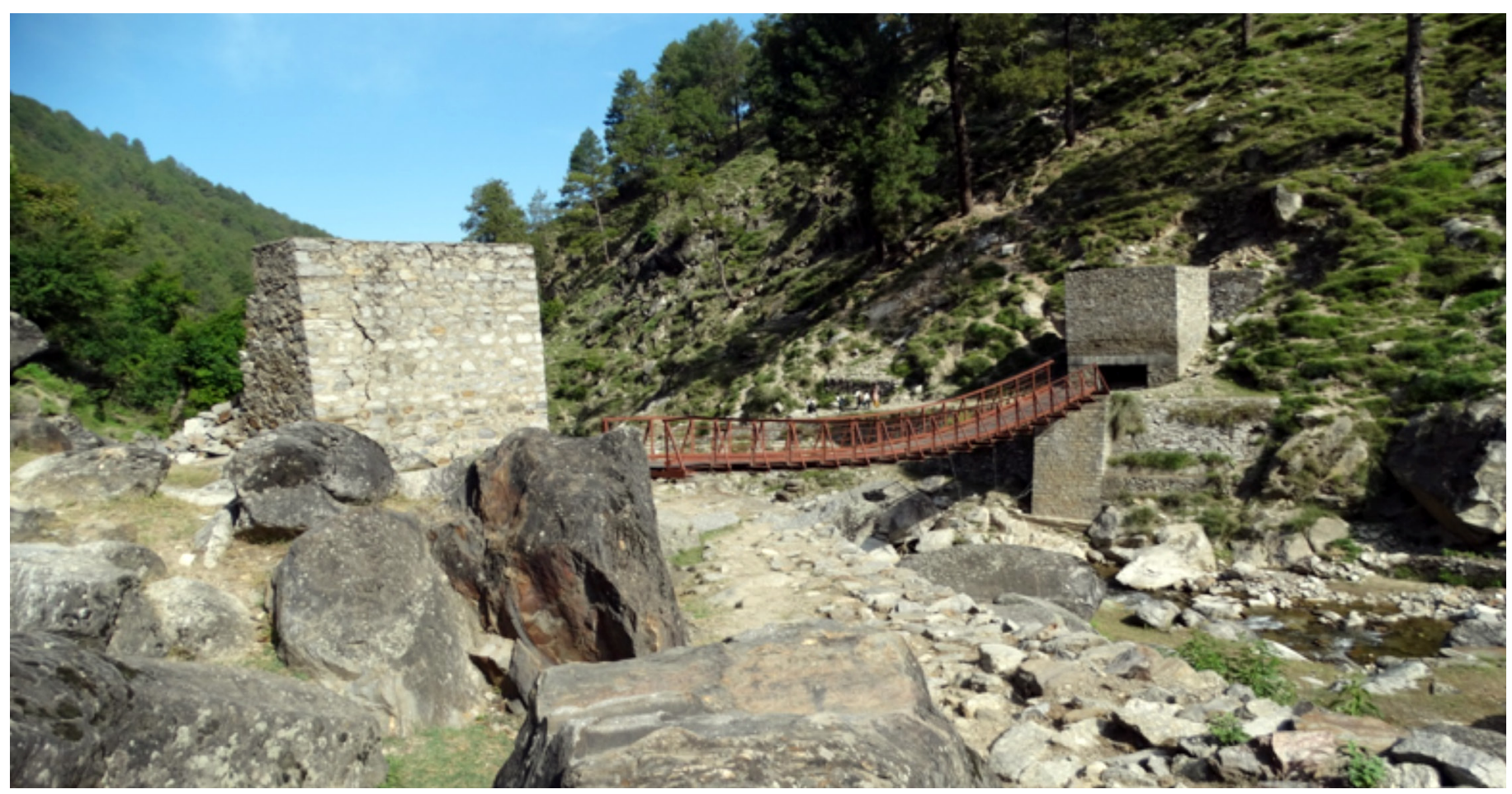

Fig. 3. The largest number of Agror Agamas (Laudakia agrorensis) encountered during surveys in the Doda Region, Jammu and Kashmir, India, were in rocky habitat with sparse vegetation near a stream. This site was near Village Chagsoo. Photograph by Amit Manhas.

cies from Jammu, India. Journal of Herpetology 12: 351-354.

Sahi, D.N. (1979). A Contribution to the Herpetology of Jammu and Kashmir. Unpublished Ph.D. Thesis, University of Jammu, Jammu and Kashmir, India.

Sahi, D.N. and P.L. Duda. 1982. Notes on little known lizards from Jammu \& Kashmir State. Journal of the Bombay Natural History Society 80(1): 227-229.

Sahi, D.N. and P.L. Duda. 1985. A checklist and keys to the amphibians and reptiles of Jammu and Kashmir State, India. Bulletin of Chicago Herpetological Society 20(3-4): 86-97.

Sahi, D.N. and P.L. Duda. 1986. Affinities and distribution of amphibians and rep- tiles of Jammu and Kashmir State (India). Bulletin of Chicago Herpetological Society 21(3-4): 84-88.

Smith, M.A. 1935. Fauna of British India, Reptilia and Amphibia. Vol. 2 (Sauria). Taylor and Francis, London, UK.

Stoliczka, F. 1872. Notes on some new species of reptiles and amphibians collected by Dr. W. Waagen in North-Western Punjab. Proceedings of the Asiatic Society of Bengal 1872: 124-131.

Uetz, P., J. Hallermann, and J. Hošek (eds.). 2016. The Reptile Database (http:// reptile-database.reptarium.cz/species?genus=Laudakia\&species=agrorensis\&s earch_param $=\% 28 \% 28$ search $\% 3 \mathrm{D} \% 27$ Laudakia + agrorensis $\% 27 \% 29 \% 29)$. 